"Abstracts from the Meteorological Observations taken at the Stations of the Royal Engineers (including $\mathrm{I}_{5}$ Colonial Stations) in the Year 1853-4, with Notes on Meteorological Subjects."

"Abstracts from the Meteorological Observations taken at the Stations of the Royal Engineers (comprising I3 British and 18 Colonial Stations) in the Years 1853-4, I8 $54-5,1855^{-6}$, I $85^{6-7}, 1857^{-8}$, and $185^{8}--9$.'

"Abstracts from the Meteorological Observations taken in the Years $1860-6 \mathrm{r}$, at the Royal Engineer Office, New Westminster, British Columbia."

These volumes will be issued without payment.

I may also mention at the same time that the Meteorological Committee, acting in accordance with the recommendation of the fourth International Conference on Scientific Aëronautics, has undertaken to subscribe for a number of copies of the international publication of the observations of the upper air on the "international days," which will be issued by Prof. Hergesell, the president of the commission. I shall be glad to know whether any scientific institution or library wishes to subscribe for a copy of this publication. The amount of the subscription is $\mathrm{I}$. per annum. W. N. SHaW.

\section{The Breeding Habits of the Tsetse-fly.}

I sHould be greatly obliged if you could find space in your columns for the following extracts from a letter which I have received from my friend Dr. A. G. Bagshawe announcing the discovery, I believe for the first time, of the pupæ of the tsetse-fly (Glossina palpalis) in nature. As this species of fly is now known to be the agent which disseminates the infection of sleeping sickness, any discoveries relating to its breeding habits are of the utmost importance from the point of view of devising measures for extirpating the fly or checking its increase. Together with my colleagues Lieuts. Gray and Tulloch, I spent a great deal of time, when I was in Entebbe, in searching for the pupæ of the fly, and we offered the native boys a rupee each for them, but all our efforts to find them in nature were unsuccessful, although captive flies deposited great numbers of pupæ in our cages. I ought, perhaps, to explain at this point that the tsetse-fly is viviparous, and produces a full-grown larva, one at a time; the larva is of a light yellowish tint when born, and wriggles about actively for an hour or so, and then turns in a short time to a dark brown pupa, about the size of a grain of wheat.

Dr. Bagshawe, who is already well known for the botanical collections he has sent home, has succeeded where we failed, and as I do not know what steps he has taken to secure the priority for this most important discovery, I hasten to make it public on his behalf. It will be seen that the pupæ have been found in the banana plantations. Since bananas are the staple food of the Baganda, it would be impossible to destroy the plantations without creating a famine. I may mention, however, that we found the tsetse-fly swarming on the deserted island of $\mathrm{Kimmi}$, on the Victoria Nyanza, where there were no plantations, so that this is perhaps not its only breeding place.

E. A. Minchin.

Lister Institute of Preventive Medicine, October 17 .

(Extract from Dr. Bagshawe's Letter.)

"On August 29 I got them [the pupæ] at last. I had marked down a particular spot as likely, and had pitched my camp near by to search. Along the lake shore for about roo yards was a belt of bananas 10-20 (40?) yards in width, and behind that undergrowth, going back roo yards or more. Fly were thick and bothered one up to sunset.

"On the second day one of the porters I had coached brought me a pupa while I was searching a hole in a tree. $\mathrm{He}$ had found it among the banana rootlets. I searched there at once, and soon found some empty pupa cases. The next day I had a lot of my people at work and 5. pupæ were found, all in the loose crumbling soil round the bananas. In the scrub behind there are none to be got. . . .

"I made a series of experiments latelv to find out how long a stretch of river the individual fly haunts. I started on the assumption that a fly with five legs is as good as one with six, and if one snipped off a piece of a known leg that fly could be identified when caught again. Six series of experiments could be made. It worked admirably. The experiments want repeating on a larger scale (I hope to do it on the Semliki), but I have shown clearly that the range is at least a mile. This is the reason why the breeding places have eluded search so long.

" (Signed) Arthur G. Bagshawe.

"Albert Edward Lake, September I, 1906."

\section{Suspended Germination of Seeds.}

IN Mr. Claridge Druce's !etter in NATURE of October II he rightly remarks that in order to prove the suspended germination of seeds. over long periods, instances are required in which the factors of wind-carried seeds, \&c., can be with some certainty eliminated. The following case, though not absolutely conclusive, may still be of interest.

Personally I am of opinion that the seed of Digitalis does preserve its germinating power for a considerable time. A few years ago I cleared a space, speaking from memory, of say forty yards by thirty yards, occupied by old Portugal laurels 25 feet to 30 feet high, planted fully sixty years ago, with Rhod. ponticum lining the path in front; the space, except on the path side, is surrounded by thick coverts. The nearest growing foxgloves were to the west along a 6-feet path running parallel with the long side of the cleared area, and distant, say, ten yards; both sides of this intervening space are lined by old rhododendrons; seed blown along would fall on the path or the edge of the clearing. The laurels were removed in January and February, when all, or nearly all, the seed would have been shed. Notwithstanding this, the next spring the whole of the cleared ground was covered with a uniform carpet of seedlings, practically hiding the bare ground. It seems to me that, even if some wind-blown seed penetrated the evergreen barrier, the seedlings would have appeared in patches.

I have known many other somewhat similar instances, but none quite so specialised as the above. I may add that the spot is exceptionally protected from wind, having tall forest trees on all sides.

Smeaton-Hepburn, Prestonkirk.

Archibald Buchan-Hepburn.

\section{Biometry and Biology.}

Owing to the proof of my letter in last week's NATURE reaching me too late for careful revision, one or two slips escaped notice. Of these; I would wish to direct attention to the interchange of the words intra-racial and inter-racia in the second paragraph on p. 609 (column I, line I4).

Biometric Laboratory, University College, London, October I9.

\section{SPEED AND STABILITY IN RAILWAY TRAVELLING.}

THE Salisbury railway accident, being followed after no very long period by the somewhat similar disaster at Grantham, undoubtedly raised a feeling of considerable uneasiness in the public mind. The recent publication by the Board of Trade of Major Pringle's report on the former calamity should do something to allay this apprehension, if only because it shows that the cause of the derailment of the train was not "mysterious," but is fully to be explained. That the evil we know is less alarming than one which vaguely threatens is a fact for which we have classic authority.

The accident occurred on July I at the Salisbury Station of the London and South-Western Railway, the train being the special boat express from Plymouth to London, carrying passengers who had arrived by the American liner New York. The train consisted of four eight-wheeled vehicles hauled by a fourNo. I 930 , vกт.. 747 